\title{
Leaves in the wind? Local policies of small and medium-sized towns in metropolitan regions
}

\author{
David Kaufmann ${ }^{\mathrm{a} *}$ and Rahel Meili ${ }^{\mathrm{b}}$ \\ ${ }^{a}$ KPM Center for Public Management, University of Bern, Switzerland; \\ ${ }^{b}$ Center for Regional Economic Development, Institute of Geography, University of Bern, Switzerland \\ *David Kaufmann, University of Bern, KPM Center for Public Management, Schanzeneckstrasse 1, 3001 \\ Bern, Switzerland, +41 (0)31 631 5996, david.kaufmann@kpm.unibe.ch \\ Published in European Planning Studies, https://doi.org/10.1080/09654313.2018.1535576
}

Small and medium-sized towns (SMSTs) contribute to the economic performance of whole metropolitan regions. However, the variety of factors that influence the economic development of SMSTs is understudied and the impact and relevance of their local policies are especially unclear. This article studies local policies of SMSTs within the metropolitan region of Zurich (Switzerland) and the impact of local policies on the economic specialization of these towns. Switzerland serves as an interesting context in which to study SMSTs, particularly those in metropolitan regions, due to their constant growth and the high local autonomy enjoyed by their local governments.-Using a multiple case study design that relies on a pair-wise comparison, we find that the economic specialization of SMSTs can mainly be explained by factors that are exogenous to local policy-making such as the town's location and its connectivity. Land-use strategies are the only local policies that can influence the economic specialization of SMSTs. Therefore, SMSTs are well advised to invest in professionalized land-use departments and to coordinate their land-use strategies with neighbouring jurisdictions. 


\section{Introduction}

Small and medium-sized towns (SMSTs) located in metropolitan regions contribute to the economic performance and success of whole metropolitan regions (Giffinger \& Suitner, 2015; Riguelle, Thomas, \& Verhetsel, 2007; Roca, Marmolejo, \& Moix, 2009). Although the metropolitan centre, i.e. the dominant city within a metropolitan region, carries most functions and economic activities, metropolitan regions compete in globalized competition as networks of several cities and towns. It is the concentration of metropolitan functions, such as financial and business services, creative industries and global transportation links, as well as the high density of highly educated workers, that make metropolitan regions powerful players in globalized interurban competition (Hall \& Pain, 2006). Thus, the prevailing research concentration on large cities and centres of metropolitan regions does not consider the diverse realities of economic growth because cities and towns within metropolitan regions interact. Furthermore, the economic performance of European cities is not correlated with city size (Parkinson, Meegan, \& Karecha, 2015). For example, since the turn of the millennium, SMSTs in Europe have performed better than large cities with regard to economic and population growth (Dijkstra, Garcilazo, \& McCann, 2013). Therefore, to better understand the development of metropolitan regions, we should also study the drivers of economic development in the SMSTs within metropolitan regions.

Studies have shown that the economic specialization of SMSTs depend on their relative distance to the metropolitan centre (Hamdouch, Demaziere, \& Banovac, 2017; Polèse \& Shearmur, 2006). Towns that are close to the metropolitan centre and towns that are better functionally integrated may be better able to 'borrow' economic specialization and performance from the metropolitan centre (Meijers \& Burger, 2015). However, this theory neglects the role of local policies. It is unclear how SMSTs strategically leverage their positions inside metropolitan regions and how they seek to deliberately influence their economic development through local 
policies. As a consequence, SMSTs’ ability to steer their economic development should be analysed in detail and not taken for granted. Savitch \& Kantor (2002) raise the question whether cities are more than just 'leaves in the wind' of economic globalization. This article down-scales this question to SMSTs as the unit of analysis. We want to find out whether SMSTs located inside metropolitan regions can influence their economic development via local policies, and thus, whether SMSTs can be more than just 'leaves in the wind'.

Against this backdrop, this article studies four SMSTs ${ }^{1}$ inside the metropolitan region ${ }^{2}$ of Zurich (Switzerland). We focus on SMSTs in Switzerland because Swiss SMSTs located within metropolitan regions are embedded in a growth context, their economic specializations vary and there is little research that studies the impact of their policies on economic specialization (Mayer \& Meili, 2017). Furthermore, Swiss local governments enjoy comparatively very high autonomy because they have authority over many policy fields, such as economic development and spatial planning, and they enjoy high tax autonomy (Sellers \& Lidström, 2007). Accordingly, we expect that Swiss SMSTs are most-likely cases (George \& Bennett, 2005), meaning that there is a higher likelihood of finding local policies that influence economic specialization in Swiss SMSTs than in SMSTs in other Western European countries.

We apply a multiple case study design and a pairwise comparison. We select two pairs of SMSTs that have a high variance in their economic specializations and that are located in the

${ }^{1}$ To be defined as a town in Switzerland, a settlement must have a density of inhabitants, jobs or equivalent for overnight stays, which sum is higher than 500 per $\mathrm{km} 2$ in a grid cell with an edge length of 300 meters (see Goebel and Kohler 2014 for more information about the definition).

${ }^{2}$ The Federal Statistical Office of Switzerland defines metropolitan regions by their commuting statistics. If agglomerations reach the threshold of a minimum of $8.3 \%$ of out-commuters to a core metropolitan region, then the agglomeration is assigned to that metropolitan region (Schuler, Dessemontet, Joye, \& Perlik, 2005). 
same region within the metropolitan region of Zurich, i.e. in Zurich South and Zurich North. More specifically, we compare towns that have a dominant knowledge-intensive business or financial service sector (KIBS/KIFS) with towns that have a residential economy sector. Through this structured comparison, we can control for regional context while maximizing differences in economic specialization.

The remainder of the article is structured as follows: In the first section, we present the literature on economic development trends and local policies in SMSTs. We derive three categories of local policies pursued by SMSTs and formulate a proposition for each category. This is followed by an outline of the multiple case study design that adopts a pairwise comparison. We then compare two SMSTs in Zurich North and two SMSTs in Zurich South. Afterwards, we analyse the findings of the comparison between these two pairs, discuss the validity of the propositions and relate the findings to the literature. Finally, we sum up and generalize the findings and formulate practical recommendations for SMSTs.

\section{SMSTs inside metropolitan regions}

SMSTs that are located inside metropolitan regions are attractive locations for firms and living spaces for people that work in the core city of a metropolitan region. In north-western European countries, high real estate prices and salaries have mostly displaced manufacturing industries out of metropolitan regions. As a result, towns inside metropolitan regions have begun to specialize in either knowledge-intensive businesses and financial services (KIBS/KIFS), or in the residential economy (Hall \& Pain, 2006; Meili \& Mayer, 2017; Serrano \& Hamdouch, 2017). Sub-centres close to metropolitan centres are able to attract KIBS/KIFS firms, such as law firms or consultancies, due to their availability of affordable land, proximity to the metropolitan centre and favourable transport connections (Glanzmann, Gabi, Kruse, Thierstein, \& Grillon, 2006). What is more, smaller urban places within metropolitan regions can combine the advantages of a 
city and those of a village and are therefore attractive places to live and to buy everyday supplies (Fertner, Groth, Herslund, \& Carstensen, 2015; Schneidewind et al., 2006). Attracting inhabitants - especially those with high incomes - increases the chance of successful urban development and economic wellbeing (Davezies, 2008). Hence, the residential economy sector - which refers to economic activities that serve local needs, such as food stores, hairdressers or schools - is another way for SMSTs to specialize and gain importance inside metropolitan regions (Segessemann \& Crevoisier, 2016).

The economic specialization of SMSTs inside metropolitan regions may depend on how integrated they are in the metropolitan region and their distance to the core city. The closer a town is to the core city of a metropolitan region, the more specialized it is (Polèse \& Shearmur, 2006). Towns that are close to a bigger city may be better able to 'borrow' economic specialization from the core city. However, the opposite can also happen and towns must cope with an 'agglomeration shadow', meaning that their proximity to the core city results in its having less functions than a town would normally have (Alonso, 1973; Meijers \& Burger, 2015). Metropolitan integration and co-operation are considered to be essential factors that allow SMSTs to benefit from the advantages that arise from the metropolitan region's scale and hence for the performance of the whole region (Cardoso \& Meijers, 2017; Meijers, Hoogerbrugge, \& Cardoso, 2017). Some barriers make metropolitan integration more difficult. A highly dominant core city and large differences in the socio-economic performance of SMSTs might lead to asymmetric power relations that hinders the willingness of SMSTs to collaborate (Rayle \& Zegras, 2013; Cardoso, 2016). According to Cardoso (2016, p. 2213) a 'leading but not dominant core city acting as a symbol of territorial identity beyond its boundaries’ as well as functional interdependence and weak hierarchies between SMSTs are necessary for a successful metropolitan integration. From an institutional perspective, metropolitan integration is fostered in 
cases of low institutional fragmentation, low local autonomy and when metropolitan governance structures are present (Kaufmann and Sager, 2018).

Swiss metropolitan regions are characterized by high institutional fragmentation, high local autonomy and the absence of metropolitan governments ${ }^{3}$, which are, for example, existent in France or the United Kingdom. However, the high functional interdependences, the weak hierarchies between and the strong consolidating role of Swiss cantons may foster metropolitan integration. As a result, for economic development to be successful, Swiss SMSTs try to balance autonomous policy initiatives as well as the coordination of policy agendas with other jurisdictions within a metropolitan region.

\section{Local policies of SMSTs in metropolitan regions}

Most studies focusing on policies in SMSTs trace the prevalent policy agendas in these towns, but they do not discuss the impact of these policies on local economic development (Kaufmann \& Arnold, 2018; Lorentzen, 2012). Moreover, it is often the case that SMSTs located in rural areas are studied and treated as regional towns or as economically unimportant (Bell \& Jayne, 2009).

Generally, evaluations of whether or not local policy initiatives could influence local economic development have been ambiguous. One problem is that the relationship between policies, institutions, governance and economic development is multi-faceted and hard to trace (Malecki, 2007; Rodríguez-Pose, 2013). Erickcek and McKinney (2006, p. 239) mention that 'several previous studies suggest that public policy actions on the state and local levels may have limited results, whereas others conclude that such actions do have positive benefits.'

\footnotetext{
${ }^{3}$ The exception is the metropolitan region of Bern. The canton of Bern enacted the establishment of a metropolitan governance institution called regional conference (Regionalkonferenz).
} 
Geographical setting, institutional framework, history and culture influence the outcome of local policy initiatives (Shearmur \& Coffey, 2002). Settlements with small governments may not have the necessary expertise to shape effective local policy initiatives. External agents and experts, however, may not have sufficient local knowledge to design tailor-made strategies (RodríguezPose, 2013).

By mainly relying on the edited volume, Creative Approaches to planning and local development - Insights from Small and Medium-sized Towns in Europe (Hamdouch et al., 2017), as well as on studies of local economic development policies in Switzerland (Berli, 2018; Devecchi, 2016; Kaufmann \& Arnold, 2018), we propose three categories of local policies that Swiss SMSTs may apply to influence their economic specialization. The local autonomy in Switzerland is high compared to other federal states. Although important policy fields, such as large-scale land-use planning, transportation, and taxation, are mostly under the control of the canton (Sager, Ingold, \& Balthasar, 2017), Swiss municipalities enjoy residual powers, which means that they can legislate and pursue their strategies in policy fields where the superior bodies have not legislated (Kaufmann et al. 2016). Given this high local autonomy, we expect to find the proposed local policies in our case studies. We derive one proposition for each of these categories, which we then test in our case studies with the help of qualitative data. To be sure, such local economic development policies cannot always be assigned unambiguously to one policy category. Local policies are formulated in packages, do not operate in isolation from each other and are often mutually dependent (Uyarra, 2010).

The first category focuses on creativity (Nyseth et al., 2017). Creativity is related to different strategies in KIBS/KIFS towns compared to towns that have a residential economy (Aarsaether et al., 2017). One strategy links the KIBS/KIFS sector to innovation through approaches that enhance knowledge interactions between economic actors inside and outside of the 
town. Innovation policies may aim to build a cluster of firms that invest in similar research and development (R\&D) activities, or they aim to promote start-ups through incubators, or they support entrepreneurship through accelerators (Kaufmann \& Arnold, 2018). Innovation policies may also include business and innovation parks that could help cluster similar firms and hence enhance knowledge transfer. Another strategy that may be applied by residential economy SMSTs focuses on the importance of culture, creative capacity and amenities in a town (for example, music concerts, architecture, design, etc.). Cultural and creative activities help to create an environment that is attractive for inhabitants. Such strategies can shape people`s sense of belonging and local experience (Førde \& Kramvig, 2017; Lorentzen, 2012). These two strategies emphasizing innovation and culture in the creativity category lead us to develop the following proposition:

- Proposition 1: Local innovation policies have contributed to a KIBS/KIFS economic specialization in SMSTs, whereas local cultural policies have contributed to a residential economic specialization in SMSTs.

The second category, which Nyseth \& Tønnesen (2017) term entrepreneurialism, aims to create closer links between public and private sectors, and has to do with tax-oriented policies and to policies that seek to promote and brand a location. Entrepreneurialism transforms the traditional role of the government from a service deliverer to a risk-taking and promotion-oriented actor (Nyseth \& Tønnesen, 2017). Low corporate tax rates attract KIBS/KIFS firms, whereas low personal income tax rates attract residents (Segessemann \& Crevoisier, 2016). Local governments in Switzerland enjoy high tax autonomy. They are allowed to levy personal income tax, corporate income tax and property tax, among others. This may lead to a tax competition for attracting residents and firms (Devecchi, 2016; Kaufmann \& Arnold, 2018). Place branding is another way to promote SMSTs, and it refers to the creation of a place identity that relates to local people, 
businesses, facilities and landscapes. Labels, such as 'Slow city’ or 'Green city’, illustrate examples of this strategy and values the social, environmental, economic or heritage-related amenities of towns (Knox \& Mayer, 2013). In sum, tax strategies and place branding appear to be versatile strategies that can be tailored to multiple target groups. We thus develop the second proposition as follows:

- Proposition 2: Low corporate tax rates and business-oriented place branding have contributed to KIBS/KIFS economic specialization in SMSTs, whereas low personal tax rates and resident-oriented place branding have contributed to residential economic specialization in SMSTs.

The third category of local policies focuses on land-use planning. SMSTs can steer the development of housing and industry or trade zones, as well as the management of land reserves, via land use planning (Berli, 2018; Devecchi, 2016). To do so, SMSTs may apply, as Serrano \& Hamdouch (2017) call it, the market of territories approach, meaning that SMSTs offer land to private actors as quickly as possible so that they build profitable business buildings or apartment blocks. Since SMSTs in metropolitan regions have, to a certain extent, the same location advantages, such as quick transportation connections and proximity to the city centre, SMSTs seek to give themselves a competitive edge by providing land before neighbouring SMSTs do (Serrano \& Hamdouch, 2017). A contrasting strategy in the land-use planning category is the archipelago approach, as it is called by Dormois (2007). This strategy emphasizes the crucial role of public authorities in land-use planning and spatial development (Serrano \& Hamdouch, 2017). Instead of selling land to the highest bidder, local authorities plan a multifunctional space that may include farmland, natural land and economic and residential areas. This approach seeks to avoid urban sprawl because it concentrates growth in certain designated areas. According to this 
theoretical background on land-use strategies, we develop the following proposition:

- Proposition 3: Land-use planning for business buildings has contributed to KIBS/KIFS economic specialization in SMSTs, whereas land-use planning for apartment buildings and single-family homes has contributed to a residential economic specialization in SMSTs.

\section{Research design}

We empirically test these theory-driven propositions through a case study design that compares four SMSTs that are located within the metropolitan region of Zurich. Our research design builds on two distinctive research heuristics that are often deployed individually in the study of European SMSTs but seldom in conjunction with each other. These heuristics are 'regional determinism' and 'territorial autonomy' (Servillo, Atkinson, \& Hamdouch, 2017). In concrete terms, this means that we control for regional context, which is important for contextual variables, but we argue that SMSTs inside a metropolitan region can actively influence their economic specialization via local policy initiatives.

We adopt a case study design that compares two pairs of SMSTs. Based on a most similar systems design logic (Przeworski \& Teune, 1970), we select pairs of SMSTs that vary in their economic specializations but that are similar to each other in regard to their contextual variables. Therefore, we select two pairs of SMSTs that are located in the same region within the metropolitan region of Zurich, i.e. in Zurich South and Zurich North. To take advantage of this pairwise comparison, we first conduct a within-pair comparison before attempting to generalize the findings in a between-pairs comparison. Investigating two similar pairs of SMSTs allows us to eliminate rival findings and allows these findings to achieve a higher level of generalizability (Blatter \& Haverland, 2014). 
The y-centred and data-driven case selection is informed by Meili \& Mayer’s (2017) cluster analysis of the economic profiles of 152 SMSTs in Switzerland. This cluster analysis groups these 152 SMSTs into seven types: prospering residential economy towns, residential economy towns, knowledge-intensive towns, business hub towns, high tech towns, low tech towns and alpine tourism towns. Most towns located in Swiss metropolitan regions belong to the knowledge-intensive town type, the business hub town type (which also has a large share of employment in the knowledge-intensive business service sector) and the residential economy type. However, the geographical pattern shows that knowledge-intensive towns and business hub towns are located near major cities, in the case of this study, in the city of Zurich, whereas residential economy towns are located further away from the city centre of Zurich (Meili \& Mayer, 2017). For our case studies, we chose two towns that serve as locations of KIBS/KIFS firms (one from the knowledge-intensive town type and one from the business hub town type) and two towns that serve the local population. By considering the importance of the distance between the towns and the city centre of Zurich, we seek to examine how the interplay between the distance to the city centre and local policies influences the economic specialization of SMSTs.

The KIBS/KIFS towns are represented by Dübendorf (Zurich North) and Adliswil (Zurich South). As Table 1 shows, Dübendorf and Adliswil are among the SMSTs with the highest share of employment in the KIBS sector in the metropolitan region of Zurich, as well as in Switzerland as a whole (BFS, 2013). Both towns are at a similar distance to the city centre of Zurich by train and by car. For the two residential towns, we chose Bülach (Zurich North) and Wädenswil (Zurich South). Both towns are part of the ranking of SMSTs with the highest share of employment (SOE) in the residential economy inside the metropolitan region of Zurich. Bülach 
and Wädenswil have nearly the same SOE in the residential economy and are at a similar distance from the city centre of Zurich. 
Table 1: Key figures of the four cases

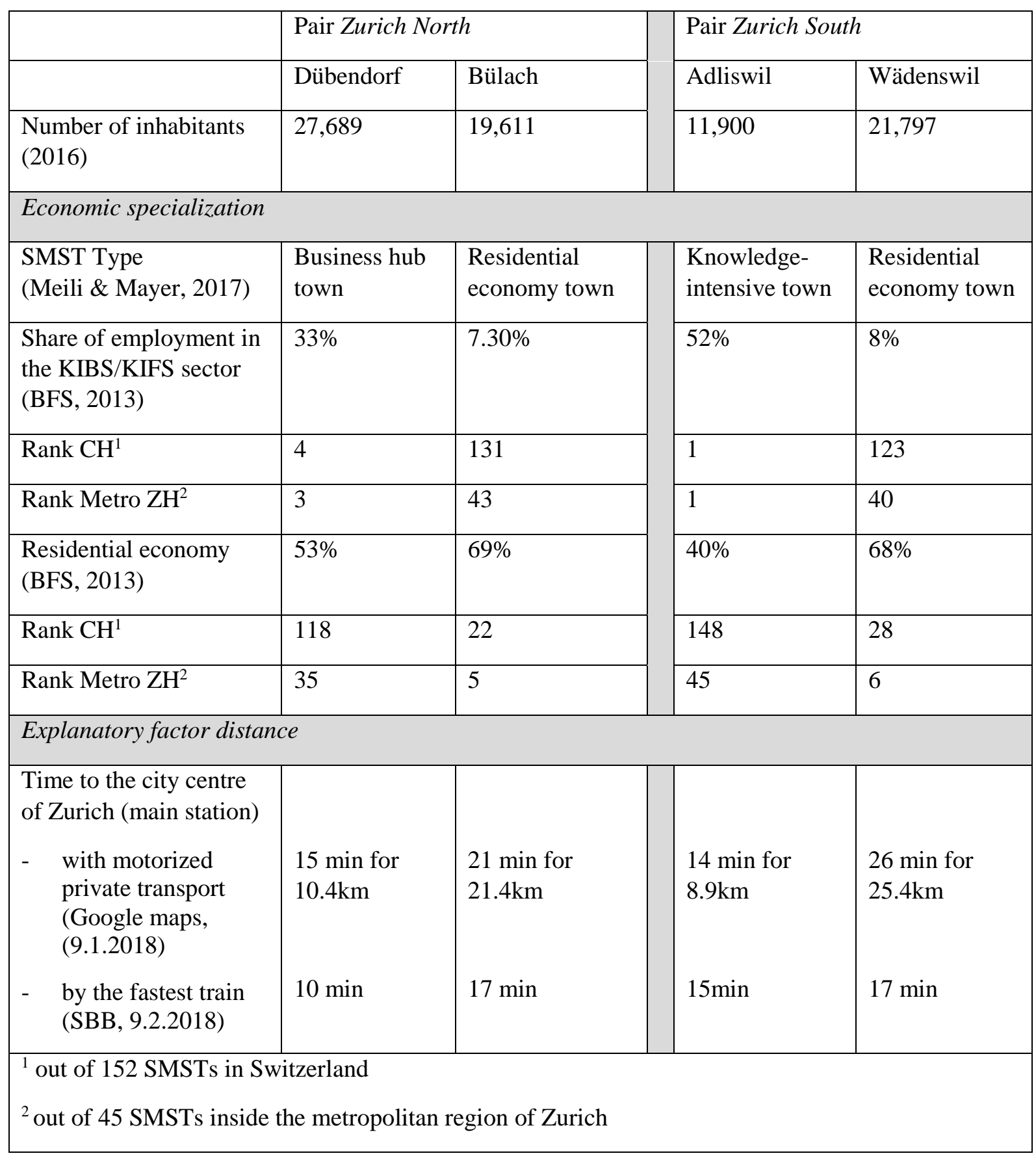

Bülach and Dübendorf are located in the north of Zurich around the Zurich Airport (the largest international airport in Switzerland). Adliswil and Wädenswil are located in the south of Zurich, in the so-called Zimmerberg region (see Figure 1). 
Figure 1: Map of the Metropolitan Region of Zurich

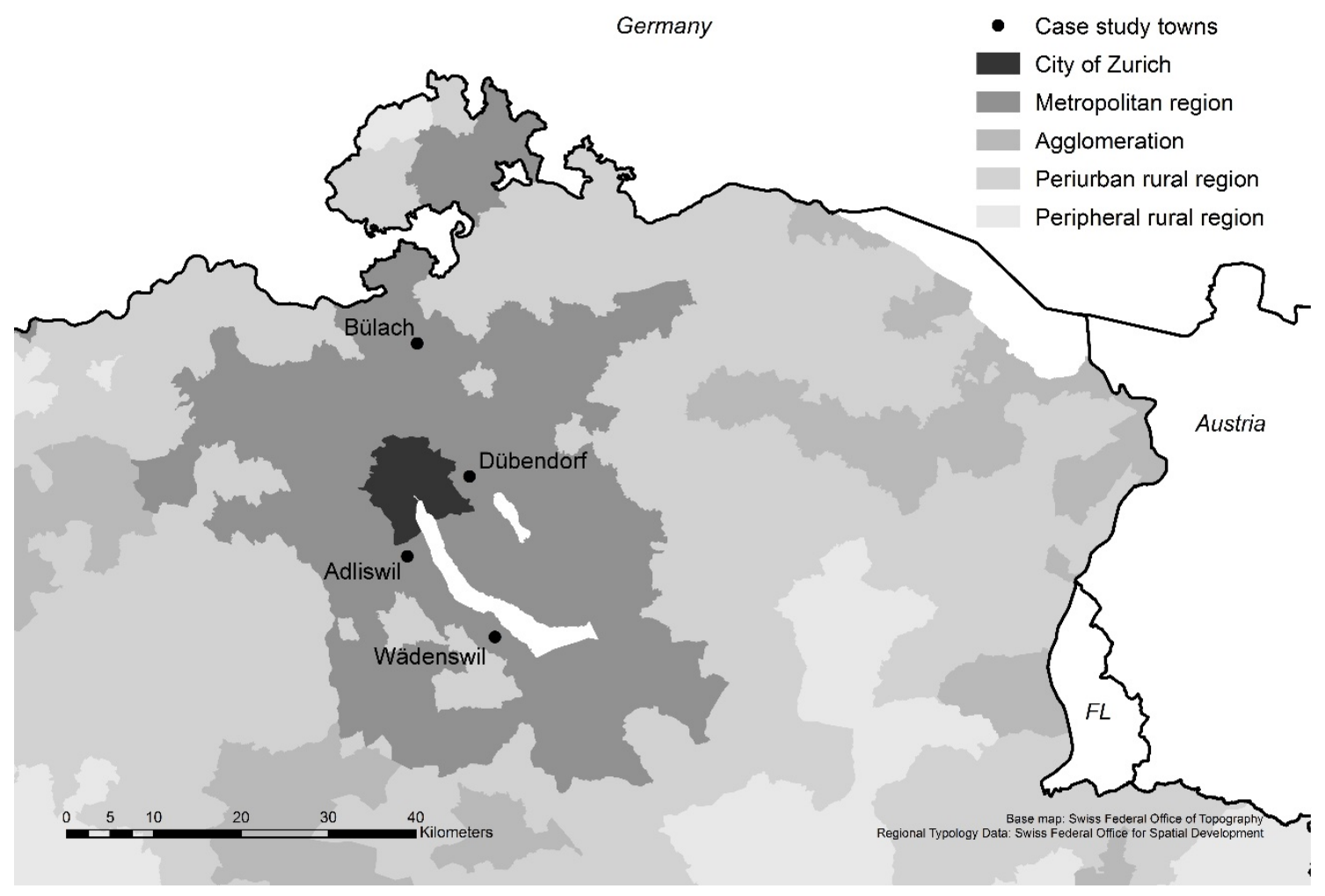

The case analysis relies on semi-structured, in-depth, elite interviews. We conducted 25 interviews (five to seven interviews per town) with relevant local politicians, local public servants, representatives from local interest groups and firms and experts (see Table A1). These interview partners were carefully selected to ensure sufficient variety within the cases, while ensuring consistency between them. The interview questions covered the general development of each town, the goals of the town's general development, the goals of the town's economic development, specific local policies and their impacts on the town's economic specialization, the impact of regional and cantonal policies on the town's economic specialization and the influence of regional dynamics on the town's economic specialization. The interviews were conducted by both authors between June and October 2017. We took extensive notes during the interviews and, after the interviews, we immediately wrote interview protocols. In a next step, we scanned the 
interview protocols for causal explanations for the economic specialization of the towns and we assign these explanations to the three local policy categories as well as to alternative policy categories and explanations, which we did not include in our local policy categories. Besides the interviews, we reviewed statistical data, reports, press articles and other secondary literature to triangulate the interviews (reactive data) with these types of non-reactive data. This data triangulation is expected to enhance the reliability of the inferences.

\section{Case studies}

We present the pair-wise comparison by first testing the propositions in the two cases related to Zurich North and then in the two cases related to Zurich South. After that, we discuss the between-pairs comparison in order to assess the possible generalizability of the findings generated by the within-pair comparisons.

\section{Within-pair comparison of Zurich North: Bülach and Dübendorf}

The land-use policy proposition is supported in both cases. We find creativity and entrepreneurialism policies in Dübendorf, mainly in accordance with our propositions. However, these policies have only been implemented recently, so they cannot have (yet) contributed to Dübendorf’s KIBS/KIFS economy.

While Dübendorf developed from a farmer town into a knowledge-intensive town in the last 200 years, Bülach developed from a farmer town into an industrial town, and it is now a residential town. Dübendorf's conversion into a knowledge-based economy was crucially affected by the establishment of the Swiss Federal Laboratories for Material Science and Technology (EMPA) in 1950 and the Swiss Federal Institute of Aquatic Science and Technology (EAWAG) in 1970. Both research institutes are affiliated with the Swiss Federal Institute of 
Technology in Zurich (ETH Zurich). Bülach was once an industrial town and its development into a residential town began in the 1980s when the majority of firms moved their production facilities abroad where production was cheaper (Interviewee 21). By mid-2000s, most industrial firms in Bülach had sold their unused land to developers, who transformed industrial brownfields into residential quarters.

Over the last decades, neither Bülach nor Dübendorf have felt the need to formulate economic development strategies on their own. Local officials from both towns explain:

We do not have to formulate economic development policies. The region, and especially Dübendorf, is very attractive. Firms settle in Dübendorf anyway. We have to be conscious of managing growth and not also fueling it (Interviewee 9).

All we have done is visit the most important employers once a year, and we have met with local business interest groups. Our economic development strategy was only to retain our existing firms (Interviewee 20).

Interview partners in both towns consider regional economic dynamics and market pressure to be more important than local policies. For example, economic globalization was mentioned several times by the interviewees as a reason for the decline of industrial production in Bülach. In another example, interview partners stressed that the development of Dübendorf must be understood within the context of the regional growth dynamics of the whole Glatt valley: Growing firms that were originally based in the city of Zurich expanded their office spaces and consolidated their dispersed locations in Dübendorf since it still had unused land that had been zoned for that purpose (Interviewees 10, 11, 12). The connectivity ensured by both train and tram is considered to be of the greatest importance for the location attractiveness for firms and research institutions in Dübendorf and for residents in Bülach (Interviewees 9 and 20). Regional growth dynamics, the distance to the city of Zurich and the connectivity of the towns are explanatory factors that are largely exogenous to local administrations. Although neither town 
formulates a comprehensive local development strategy, they both still pursue individual strategies that aim to influence their economic specialization, as will be outlined in the following section.

\section{Creativity and entrepreneurialism}

While Bülach has not formulated local policies based on the creativity or entrepreneurialism approach, Dübendorf connects the two approaches. ${ }^{4}$ Dübendorf attempts to position itself as research town by supporting the development of an innovation park and by marketing the presence of the federal research institute. A consortium of national, cantonal and local politicians and ETH representatives was successful in establishing a Swiss Innovation Park, financially supported by the Swiss Federation, on the premises of a decommissioned military airport (Interviewee 8). The municipality of Dübendorf was not the main initiator behind the establishment of the innovation park, but the municipality strategically refrained from selling the land of the airport, which has become vacant, to developers. This strategy maintained the space necessary for realizing such a large-scale project (Interviewees 8 and 9). The construction began in summer 2017. The innovation park is expected to serve as a collaborative platform between universities, research institutions and KIBS firms with the goal of fostering innovation and commercialization in life sciences, engineering and environment, and digital technologies. The presence of knowledge-intensive firms, research institutes and the innovation park is actively marketed given that it is a concrete goal of the 2014-2018 parliamentary legislative term

\footnotetext{
${ }^{4}$ Both towns have outsourced part of their location promotion activities to regional economic promotion organizations: Bülach to the organization Location Zurich Lowlands (Standort Zürcher Unterland) and Dübendorf to the organization Airport Region Zurich.
} 
(Interviewee 9). However, the marketing of Dübendorf as a city of research only began recently. Only once the federal research institutes were already in place did the local authorities realize the economic potential of their research organizations as part of today’s knowledge economy.

\section{Land-use planning}

Land-use policies are the only local policy instrument that interview partners from Bülach and Dübendorf consider to be effective instruments for influencing local economic specialization. Both towns had available land and both initially pursued a market of territories approach before turning to an archipelago approach.

Dübendorfs`development into a knowledge-intensive town began in 1950, when the EMPA settled in Dübendorf because the municipality owned land that it urgently wanted to sell. Local historians explain the market of territories approach that Dübendorf pursued at the time:

Dübendorf needed money and the municipality owned a spot of land. They sold the land to the bidder with the highest price. The federation was the only bidder. If someone else had paid more money per square meter, the EMPA would not be in Dübendorf today (Interviewee 12).

In Bülach, land reserves in the south of town were also sold to different developers without a coherent land-use plan (Interviewees 19 and 23). Most developers built residential houses. Given that the local authorities refrained from formulating a land-use plan for these land reserves, South Bülach was sprawling so chaotically that 'the executive council adopted a planning moratorium to obtain a construction stop. The market just overran us' (Interviewee 20).

Today, profound land-use regulations are employed in Dübendorf and Bülach. Cantonal authorities have designated parts of both towns as a so-called Cantonal Centre Area (Kantonales Zentrumsgebiet, CCA). The canton of Zurich seeks to concentrate the growth of the built 
environment in these areas in order to combat urban sprawl. This designation allows local authorities to adopt more profound building regulations regarding the percentage of residential and non-residential buildings that can be built and the quality and the density of the built environment in this area. Based on this opportunity for profound regulation, Dübendorf aims to create a mixed-use development of housing and business premises. Rather than actively attract firms via land-use planning, Dübendorf seeks to prevent unwanted firms and industries from settling in the local CCA (Interviewee 9). Bülach predominantly uses the CCA to plan for housing units, but it reserves ground floor premises for retail stores (Interviewees 19 and 20). Overall, it appears that Dübendorf's decision to focus on mixed-use development and Bülach's decision to focus on housing units were mostly aligned to the demands of the market. The local authorities refrained from trying to steer the economic specialization of the towns in a different direction.

The CCA strategy is decisive for explaining growth in the Glatt valley. For example, a new tram line in the Glatt valley, which was financed by the canton and the federation due to the CCA status of multiple areas in the Glatt valley, cost around 1 billion Swiss Francs, but it has induced another 6 billion Swiss Francs in investments around the newly developed tram line (Interviewee 11). This tram line connects the patchwork of different growth archipelagos in Zurich North. The original impulse for the tram line was generated by informal meetings between four Glatt valley mayors, one of which was the mayor of Dübendorf, in the early 1990s (Nüssli \& Schmid, 2016).

\section{Within-pair comparison of Zurich South: Adliswil and Wädenswil}

No proposition can fully be supported in the two Zurich South cases. Adliswil has focused its land-use planning on businesses and housing, whereas Wädenswil has planned for business and 
research and education institutions, as well as housing. With regard to the two propositions on creativity and entrepreneurialism, we find that the residential economy town of Wädenswil is more active than Adliswil, the KIBS/KIFS town.

While both Adliswil and Wädenswil were industry towns in the 19th century, they followed different development paths during the 20th century. Adliswil’s economy developed into a knowledge-intensive economy, hosting major insurance companies, whereas Wädenswil developed into a residential town with a focus on education and research. In the 1990s, Adliswil benefited from the lack of office space in the city of Zurich. Big firms, such as the re-insurance company Swiss Re, moved to Adliswil and established themselves on industrial brownfields that Adliswil zoned accordingly (Interviewee 7). In Wädenswil, most of the industrial brownfields were transformed into housing due to high demand and the profitability of housing units (Interviewee 14). The origin of Wädenswil's education and research focus lies on the agricultural research and education centre that was founded in 1890 on land that was made available by the bailiwick (Interviewee 15). Today, Zurich University of Applied Sciences (Zürcher Hochschule für Angewandte Wissenschaften, ZHAW) has its department of Life Science and Facility Management in Wädenswil.

Although authorities in Wädenswil invest more in economic development policies when compared to their counterparts in Adliswil, the respective interview partners agree that the influence of local economic development policies is limited. Despite not having employed anyone who is solely responsible for economic development, a regional location promoter states that Wädenswil is one of the only towns in the region that has its own development strategy, which has a research and education focus (Interviewee 4). Wädenswil’s further distance from Zurich is seen as a disadvantage when luring big national and international firms to the town (Interviewees 13 \& 17). However, the distance to Zurich is not too far to attract out-commuters 
and education and research institutions. The economic specialization of Adliswil is the result of its proximity to the city of Zurich, the availability and zoning of land and the ease of connectivity to it. Contrary to its economic specialization, its image as a residential town dominates local development discussions (Interviewee 1).

Adliswil has never formulated an economic development strategy. One Member of Parliament stated that it might be that Adliswil is currently too well off to be forced to think about economic development issues (Interviewee 5). Other than local land-use policies, the authorities of Adliswil consider themselves to be without the competence, time and monetary resources for comprehensive local development and location promotion issues (Interviewees 1 and 4). Additionally, authorities or politicians do not consider themselves to be in a position to significantly influence market dynamics or the relocation decisions of big national or international firms as, for example, the mayor of Adliswil explains:

As a small town you can do nothing. You can only make little changes - maybe improve schools and leisure activities (Interviewee 1).

\section{Creativity and entrepreneurialism}

While Adliswil has not formulated local policies based on the creativity or entrepreneurialism approach, Wädenswil links the creativity approach to the entrepreneurialism approach by focusing on education and research. ${ }^{5}$ Different strategies seek to position Wädenswil as an education and research centre (Interviewees 13 and 18). First, the town buys and renovates buildings for educational purposes and ensures reliable public transport to improve the

\footnotetext{
${ }^{5}$ Both towns have outsourced parts of their location promotion to the regional economic promotion organization called Zurich Park Side.
} 
infrastructure and accessibility of schools. Second, the town is a partner of a local business incubator called Grow. Third, the local cluster organization, 'Foodplus’, aims to develop cooperation between economic actors, schools and research institutions (Interviewee 17). These activities are accompanied by place branding instruments, such as the slogan 'Bildungs- und Forschungsstadt am Zürichsee’ (Education and Research town at the lake of Zurich). This focus on education and research may have helped the town to be chosen as the new location for a cantonal secondary school (Interviewee 13).

Besides promoting Wädenswil as an education and research town, authorities have attracted new firms to Wädenswil by providing affordable land in a newly established business land-use zone close to the motorway at the edge of the town (Interviewee 13). Not only is expected that new industries will be attracted to Wädenswil because of this new zone, but also local businesses that do not have enough space will be encouraged to stay in Wädenswil. Some firms that had left Wädenswil, due to a shortage of land, have already returned to this new business zone, including a construction firm (Interviewee 16). However, due to its location at the edge of the town, the business zone is not expected to be attractive to service firms (Interviewee 13).

\section{Land-use planning}

Local land-use policies are important in both towns and both towns currently employ an archipelago approach to local land-use planning. No area in Adliswil or Wädenswil is designated as a CCA. Adliswil's local land-use planning has supported the development of industrial brownfields into places that are suitable for service firms and residents. Given the presence of research and education institutions, Wädenswil seeks to attract businesses, research organizations and residents via land-use planning. 
Similar to Bülach and Dübendorf, Adliswil and Wädenswil had available land that was sold by private owners or the town to the highest bidder, according to the market of territories approach (Interviewee 7). Whereas residential houses and new buildings for education and research institutions were built in Wädenswil, office buildings for service firms and housing were built in Adliswil. However, the area close to where service companies have located has been the focus of general land-use planning since the early 2000s because it is close to the motorway and has good connections to the city of Zurich (Interviewee 3). The town of Adliswil has started to comprehensively plan the development of available land for housing and businesses and shifted from a market of territory approach to a more integrated archipelago approach to prevent unorganized urban sprawl. So far, an international school has settled there and residential buildings with around 461 apartments and a park have been constructed. Similarly, Wädenswil authorities highlight the fact that they can steer development via official zone planning. As one local official explains:

When developers want to have special permits, we can give those under certain conditions. This way, we can - to a certain extent - decide how much of the new buildings should be for housing or businesses. (Interviewee 14)

\section{Between-pairs comparison}

The between-pairs comparison reveals that only the proposition about land-use planning can be partially supported. The propositions regarding creativity and entrepreneurialism are only supported in the case of Dübendorf, and they, therefore, have to be rejected. The pairwise comparison also demonstrates that the distance to the city of Zurich, as an exogenous explanatory factor, is relevant for explaining the development of economic specializations in Zurich North and in Zurich South. Table 2 summarizes the pairwise comparison. In this section, we discuss each proposition and potential exogenous factors. 

Table 2: Case comparison

\begin{tabular}{|c|c|c|c|c|}
\hline & \multicolumn{2}{|l|}{ Zurich North } & \multicolumn{2}{|l|}{ Zurich South } \\
\hline & Dübendorf & Bülach & Adliswil & Wädenswil \\
\hline $\begin{array}{l}\text { Economic } \\
\text { specialization }\end{array}$ & Knowledge-intensive town & Residential economy town & Knowledge-intensive town & $\begin{array}{l}\text { Residential economy town with a } \\
\text { research and education focus }\end{array}$ \\
\hline Propositions & $\begin{array}{l}\text { 1. Innovation policies } \\
\text { 2. Low corporate tax rates and } \\
\text { business-oriented place branding } \\
\text { 3. Land-use planning for business }\end{array}$ & $\begin{array}{l}\text { 1. Cultural policies } \\
\text { 2. Low personal tax rates and } \\
\text { resident-oriented place branding } \\
\text { 3. Land-use planning for residents }\end{array}$ & $\begin{array}{l}\text { 1. Innovation policies } \\
\text { 2. Low corporate tax rates and } \\
\text { business-oriented place branding } \\
\text { 3. Land-use planning for business }\end{array}$ & $\begin{array}{l}\text { 1. Cultural policies } \\
\text { 2. Low personal tax rates and } \\
\text { resident-oriented place branding } \\
\text { 3. Land-use planning for residents }\end{array}$ \\
\hline $\begin{array}{l}\text { Empirically } \\
\text { observed local } \\
\text { policies }\end{array}$ & $\begin{array}{l}\text { 1. Creativity } \checkmark \\
\text { 2. Research-oriented place } \\
\text { branding ( } \checkmark \text { ) } \\
\text { 3. Availability of land and local } \\
\text { land-use planning: } \checkmark \\
\text { - } \quad \text { From market of territories to } \\
\text { archipelago approach } \\
\text { - } \quad \text { Business, research and } \\
\quad \text { housing }\end{array}$ & $\begin{array}{l}\text { 1. - } \downarrow \\
\text { 2. - } \downarrow \\
\text { 3. Availability of land and local } \\
\text { land-use planning: } \checkmark \\
\text { - From market of territories to } \\
\text { archipelago approach } \\
\text { - Housing }\end{array}$ & $\begin{array}{l}\text { 1. }-\checkmark \\
\text { 2. }-\checkmark \\
\text { 3. Availability of land and local } \\
\text { land-use planning: ( } \mathfrak{c}) \\
\text { - } \quad \text { From market of territories to } \\
\text { archipelago approach } \\
\text { - } \quad \text { Business and housing }\end{array}$ & $\begin{array}{l}\text { 1. Creativity } \checkmark \\
\text { 2. Research and education- } \\
\text { oriented place branding and } \\
\text { industry zone } \checkmark \\
\text { 3. Availability of land and local } \\
\text { land-use planning: ( } \checkmark \text { ) } \\
\text { - } \quad \text { From market of territories to } \\
\text { archipelago approach } \\
\text { - } \quad \text { Housing, business and } \\
\text { research/education }\end{array}$ \\
\hline $\begin{array}{l}\text { Empirically } \\
\text { observed } \\
\text { exogenous factors }\end{array}$ & $\begin{array}{l}\text { Cantonal growth strategy } \\
\text { Economic dynamism of the } \\
\text { region } \\
\text { Nearer to the city of Zurich }\end{array}$ & $\begin{array}{l}\text { Cantonal growth strategy } \\
\text { Economic dynamism of the region }\end{array}$ & Nearer to the city of Zurich & $\begin{array}{l}\text { Further away from the city of } \\
\text { Zurich }\end{array}$ \\
\hline
\end{tabular}

Notes: Not-shared, and thus explanatory, factors are in italics. Thick marks indicate whether or not the proposition is supported. A $\checkmark$ means it is fully

supported, $(\checkmark)$ means it is partially supported, and $\checkmark$ means it is not supported 
Interview partners in Zurich North and Zurich South emphasize the importance of landuse planning to influence local economic development. The distinction between landuse planning and the entrepreneurialism or creativity categories is not as clear-cut as we proposed in our categorization of local policies. Both KIBS/KIFS towns (Adliswil and Dübendorf) plan mixed-use development (i.e. housing and business). The residential town of Bülach mainly plans for housing development, whereas the residential economy town of Wädenswil plans for housing, business (but not so much for knowledgeintensive firms) and research organizations. In general, these four SMSTs do not possess much property. Instead, they try to influence property development via land-use planning. We find that the archipelago approach to land-use planning is currently prevalent in all four SMSTs. This means that instead of just selling land to the highest bidder, authorities plan designated growth areas (Dormois, 2007; Serrano \& Hamdouch, 2017). However, the economic specializations of the towns were largely determined by the market of territories approach during the 1980s and 1990s, when industrial brownfields, or other building land, were zoned accordingly and then sold to the highest bidder. Back then, the distance to Zurich was the crucial factor for attracting investors. In both Zurich North and Zurich South, large service firms looking to consolidate or expand their office spaces sought available land in towns close to the city of Zurich, which were well connected by train and by car. The distance from both Wädenswil and Bülach to the city of Zurich appears to be too far to attract knowledge-intensive firms. However, these towns are attractive to residents. Thus, towns that are close to a bigger city may be able to 'borrow’ economic specialization from their larger counterparts (Alonso, 1973; Meijers \& Burger, 2015).

In sum, the between-pairs comparision shows that land-use policies are currently implemented in line with our propositions in Zurich North, but only partially in line 
with them in Zurich South. The impact of land-use policies seems limited given the prevalence of the market of territories approach that reigned during the time when economic specializations were emerging. Thus, proposition 3 can only partially be supported. Additionally, the distance to the city of Zurich emerged as an important exogenous explanatory factor in both pairs of SMSTs.

We only found traces of innovation policies (creativity) and research-oriented place branding (entrepreneurialism) in Dübendorf (KIBS/KIFS town) as well as in Wädenswil (residential economy town), meaning that propositions 1 and 2 must be rejected since these two towns have different economic characteristics. Regarding innovation policies, both Dübendorf and Wädenswil formulate cluster building strategies. Dübendorf is partner in an innovation park project that is expected to spatially concentrate knowledge interactions. Wädenswil seeks to generate the same effect by applying a cluster approach in the education and research fields, as well as in the food sector. Thus, contrary to proposition 1, it seems that innovation policies are implemented in towns that have a research focus and not generally in KIBS/KIFS towns. Place-branding, which belongs to the entrepreneurialism category, is completely outsourced to regional location promotion agencies in Adliswil and Bülach. These two towns settle for being branded as 'part of' Zurich (Zurich Park Side or Airport Region Zurich) given that Zurich has a high international visibility. Meanwhile, Dübendorf and Wädenswil pursue - additionally to their membership in the region location promotion agencies - their own place branding strategies as towns of research and, in the case of Wädenswil, of research and education. In the two towns with a residential economic specialization, Bülach and Wädenswil, we found no strategies that exploit social or environmental amenities to brand the locations as residential towns. Thus, contrary to proposition 2, it seems that research and education are especially suited to place 
branding in the today's knowledge-intensive economy. However, local authorities in both towns jumped on the bandwagon, i.e. they market local assets that are already available. Tax policies, which also belong to the entrepreneurialism category, have not been considered to be very important at the local level. Instead, they are rather used as an instrument of the canton of Zurich.

Overall, interviewees do not generally consider local policies to be very effective for impacting local economic development or the economic specialization of SMSTs. One reason for this is that local governments seem to lack the expertise and the resources to formulate effective local economic development policies. Additionally, the impact of local policies on larger market dynamics and regional growth dynamics is limited. Furthermore, the cantons are the most influential political entities in Swiss policy making (Sager, Ingold, \& Balthasar, 2017). This dominance of the cantons in combination with high local autonomy and high institutional fragmentation has led to interlocking politics and a high degree of policy cooperation between all three governmental levels in Switzerland (Kübler 2007)

Through the association “Metropolitan Region Zurich” cantons, cities as well as municipalities in the metropolitan region should be encouraged to cooperate and coordinate their policies. However, as the interviews show, many SMSTs do not feel addressed by discussions and policy initiatives in this association and they see the city of Zurich and the canton of Zurich as much more important in influencing economic development. However, SMSTs in Zurich North and South cooperated with each other in certain policy fields, for example in transportation, to launch policy initiatives and to increase their political weight vis-à-vis the canton.

\section{Conclusion}

This article studies the local policies that four SMSTs located inside the metropolitan 
region of Zurich formulate in order to influence their economic specializations and investigates the impact of these policies. We distinguish between three categories of local policies that SMSTs can apply, namely, creativity, entrepreneurialism and landuse planning. We formulate one proposition for each category, which we test in four cases. We compare two pairs of SMSTs in Zurich North and Zurich South. In both pairs, we select a town with a dominant KIBS/KIFS sector and a town that possesses a strong residential economy.

Our comparison reveals that the economic development and the economic specialization of SMSTs are largely exogenous to local policy-making. The location of the town together with its connectivity best explain whether a SMST develops into a KIBS/KIFS town or a residential town. If the distance to the city of Zurich becomes too large, a SMST loses its attractiveness for knowledge-intensive firms and develops into a residential town. Local policies are found to have a limited impact on the local economic specialization of towns. SMSTs lack expertise and administrative professionalization and seem to be too small-scale to influence economic development. The only exception is regarding local land-use planning. Many interviewees mentioned land-use planning, either through active land-use planning or zoning decisions, as important for the economic development of SMSTs. Over the last couple of years, all four SMSTs under scrutiny moved from a market of territories approach, which offers land to private actors, to an archipelago approach, which designates growth areas within the town. Land-use planning is also an instrument to enhance a town's attractivity for economic activities and for specific firms. Hence, land-use planning strategies can incorporate attributes of entrepreneurialism or creativity strategies. In general, these local economic development policies do no operate in a vacuum, but they are influenced 
by regional factors as well as decision of higher-tier governments. Nevertheless, these policies are essentially local since they are formulated and implemented by local actors.

These findings may be generalized to SMSTs in other Swiss metropolitan regions as well as to SMSTs in other West European polycentric urban systems. The metropolitan region of Zurich is one of the economically strongest Swiss regions (BFS 2017). Hence, SMSTs inside this region that are well connected to the city of Zurich benefit directly from favourable regional dynamics. Therefore, local economic development policies might have less of an effect in these SMSTs and there might be less of an urge to formulate local economic development policies. SMSTs in economically weaker regions may have more of an urge to devise local economic development policies and they may be more creative in their local economic development strategies. With regard to SMSTs in other Western European countries, our findings suggest that these SMTSs have only limited influence to steer their economic development because Swiss SMSTs are most likely cases in which we would find an impact of local policies on the economic specialization of towns. This generalization can be applied to similar polycentric urban systems in the Blue Banana (also known as the Manchester-Milan Axis), such as England, The Netherlands, Belgium, Western and South Germany and Northern Italy (Brunet, 1989). However, these findings should be generalized with caution given the small size of our unit of analysis that makes local economies vulnerable to distortions caused by idiosyncratic events. In Dübendorf, for example, the EMPA’s decision to move to Dübendorf was pure luck and was not initiated by local leaders. The presence of the EMPA was an important factor for the development of knowledge-intensive business activities in Dübendorf. In Wädenswil, the bailiwick donated land that then laid the foundation for the town's research and education focus. Thus, idiosyncratic events may constitute so- 
called critical junctures that can shape the economic specialization of towns through path-dependent feedback effects.

Our case studies and the interviews allow us to draw practical implications for decision-makers in SMSTs. Active land-use planning seems to be the key for managing a town during the turmoil of economic globalization. Active land-use planning depends on a professionalized administration. Thus, SMSTs are well advised to invest in professionalized land-use and town planning departments. A professionalized land-use administration has leverage in negotiations with investors and developers because they can make use of the competition between them (Devecchi, 2016). Given the spatial characteristics of land-use planning, SMSTs may also want to coordinate their land-use policies with neighbouring jurisdictions. This would not only enhance the effectiveness of land-use policies, but it would also increase the political leverage of SMSTs in cantonal land-use decisions. SMSTs would presumably benefit from a strengthening of metropolitan institutions, but given that this is unlikely in Switzerland, SMSTs should seek strategic alliances to coordinate their policies and strategies within the region. SMSTs that coordinate their land-use strategies can initiate new regional projects, as the example of the tramline in the Glatt Valley shows.

SMSTs are certainly challenged by the economic dynamics of globalization and they only have few policy instruments at hand, but they are not bound to be 'leaves in the wind' (Savitch and Kantor 2002), if they invest in a professionalized land-use planning that is coordinated among neighbours. Thus, SMSTs should strengthen their local autonomy by professionalizing their land-use planning, while simultaneously seeking strategic alliances to coordinate their land-use planning strategies within the region. 


\section{Bibliography}

Aarsaether, N., Serrano, J., Førde, A., Demazière, C., Nyseth, T., \& Hamdouch, A. (2017). Postscript: pathways towards a critical and comparative approach to creative planning. In A. Hamdouch, T. Nyseth, C. Demazière, A. Førde, J. Serrano, \& N. Aarsaether (Eds.), Creative approaches to planning and local development. Insights from small and medium-sized towns in Europe (pp. 249257). Oxon: Routledge.

Alonso, W. (1973). Urban Zero Population Growth. Daedalus, 102(4), 191-206.

Bell, D., \& Jayne, M. (2009). Small cities? Towards a research agenda. International Journal of Urban and Regional Research, 33(3), 683-699.

Berli, J. (2018). Competition in local land use planning? Journal of Public Policy, 38(1), 27-56.

BFS. (2013). STATENT 2013. Neuchâtel: BFS.

BFS. (2017). Bruttoinlandprodukt pro Kanton und Grossregion. Neuchâtel: BFS.

Blatter, J., \& Haverland, M. (2014). Designing Case Studies. Explanatory Approaches in Small-N Research. Hampshire: Palgrave macmillan.

Brunet, R. (1989). Les villes européennes: rapport pour la DATAR, Délégation à l'Aménagement du Territoire et à l'Action Régionale. Montpellier: RECLUS.

Cardoso, R. V. (2016). Overcoming barriers to institutional integration in European second-tier urban regions. European Planning Studies, 24(12), 2197-2216.

Cardoso, R. V., \& Meijers, E. J. (2017). Secondary Yet Metropolitan? The Challenges of Metropolitan Integration for Second-Tier Cities. Planning Theory and Practice, 18(4), 616-635.

Davezies, L. (2008). La République et ses Territoires. Paris: Editions du Seuil.

Devecchi, L. U. (2016). Zwischenstadtland Schweiz: Zur politischen Steuerung der suburbanen Entwicklung in Schweizer Gemeinden. Bielefeld: transcript Verlag.

Dijkstra, L., Garcilazo, E., \& McCann, P. (2013). The Economic Performance of European Cities and City Regions: Myths and Realities. European Planning Studies, 21(3), 334-354.

Dormois, R. (2007). Pour une analyse dynamique des ressources dans la conduite de l’action publique. In H. Gumuchian \& B. Pecqueur (Eds.), La ressource territoriale (pp. 49-65). Paris: Economica-Anthropos. 
Erickcek, G. A., \& McKinney, H. (2006). “Small Cities Blues:” Looking for Growth Factors in Small and Medium-Sized Cities. Economic Development Quarterly, 20(3), 232-258.

Fertner, C., Groth, N. B., Herslund, L., \& Carstensen, T. A. (2015). Small towns resisting urban decay through residential attractiveness. Findings from Denmark. Geografisk Tidsskrift-Danish Journal of Geography, 115(2), 119-132.

Førde, A., \& Kramvig, B. (2017). Cultural industries as a base for local development. In A. Hamdouch, T. Nyseth, C. Demazière, A. Førde, J. Serrano, \& N. Aarsaether (Eds.), Creative approaches to planning and local development. Insights from small and medium-sized towns in Europe (pp. 81-96). Oxon: Routledge.

George, A., \& Bennett, A. (2005). Case studies and theory development in the social sciences. Boston: MIT Press.

Giffinger, R., \& Suitner, J. (2015). Polycentric Metropolitan Development: From Structural Assessment to Processual Dimensions. European Planning Studies, 23(6), 1169-1186.

Glanzmann, L., Gabi, S., Kruse, C., Thierstein, A., \& Grillon, N. (2006). European Metropolitan Region Northern Switzerland: Driving Agents for Spatial Development and Governance Responses. In P. Hall \& K. Pain (Eds.), The Polycentric Metropolis. Learning from mega city regions in Europe (pp. 172186). London: Earthscan.

Goebel, V., \& Kohler, F. (2014). Raum mit städtischem Charakter 2012. Erläuterungsbericht. Neuchâtel: Bundesamt für Statistik (BFS).

Hall, P., \& Pain, K. (2006). From Metropolis to Polypolis. In P. Hall \& K. Pain (Eds.), The Polycentric Metropolis. Learning from mega city regions in Europe (pp. 416). London: Earthscan.

Hamdouch, A., Demaziere, C., \& Banovac, K. (2017). The Socio-Economic Profiles of Small and Medium-Sized Towns: Insights from European Case Studies. Tijdschrift Voor Economische En Sociale Geografie, 108(4), 457-471.

Hamdouch, A., Nyseth, T., Demazière, C., Førde, A., Serrano, J., \& Aarsaether, N. (Eds.). (2017). Creative approaches to planning and local development. Oxon: Routledge.

Kaufmann, D., Warland, M., Mayer, H., \& Sager, F. (2016). Bern’s positioning strategies: Escaping the fate of a secondary capital city? Cities, 53, 120-129. 
Kaufmann, D., \& Arnold, T. (2018). Strategies of cities in globalised interurban competition: The locational policies framework. Urban Studies, 55(12): 27032720.

Kaufmann, D., \& Sager, F. (2018). How to organize secondary capital city regions: Institutional drivers of locational policy coordination. Governance. Early Online.

Knox, P. L., \& Mayer, H. (2013). Small Town Sustainability (2nd ed.), Basel: Birkhäuser.

Kübler, D. (2007). Agglomerations. In U. Klöti, P. Knopfel, H. Kriesi, W. Linder, Y. Papadopoulos \& P. Sciarini (Eds), Handbook of Swiss Politics (pp. 253-278), Zurich: NZZ Libro.

Lorentzen, A. (2012). Sustaining small cities through leisure, culture and the experience economy. In A. Lorentzen \& B. van Heur (Eds), Cultural Political Economy of Small Cities (pp. 65-79). Oxon: Routledge.

Malecki, E. J. (2007). Cities and regions competing in the global economy: Knowledge and local development policies. Environment and Planning C: Government and Policy, 25(5), 638-654.

Meijers, E., \& Burger, M. (2015). Stretching the concept of “borrowed size”. Urban Studies, 54(1), 1-23.

Meijers, E., Hoogerbrugge, M., \& Cardoso, R. (2017). Beyond Polycentricity: Does Stronger Integration Between Cities in Polycentric Urban Regions Improve Performance? Tijdschrift Voor Economische En Sociale Geografie, 109(1), 1-21.

Meili, R., \& Mayer, H. (2017). Small and medium-sized towns in Switzerland: Economic heterogeneity, socioeconomic performance and linkages. Erdkunde, 71(4), 313-332.

Nüssli, R., \& Schmid, C. (2016). Beyond the Urban-Suburban Divide: Urbanization and the Production of the Urban in Zurich North. International Journal of Urban and Regional Research, 40 (3), 679-701.

Nyseth, T., Hamdouch, A., Demazière, C., Aarsaether, N., Førde, A., \& Serrano, J. (2017). Perspectives on creative planning and local development in small and medium-sized towns. In A. Hamdouch, T. Nyseth, C. Demazière, A. Førde, J. Serrano, \& N. Aarsaether (Eds.), Creative approaches to planning and local development. Insights from small and medium-sized towns in Europe (pp. 1321). Oxon: Routledge. 
Parkinson, M., Meegan, R., \& Karecha, J. (2015). City Size and Economic

Performance: Is Bigger Better, Small More Beautiful or Middling Marvellous? European Planning Studies, 23(6), 1-15.

Polèse, M., \& Shearmur, R. (2006). Growth and location of economic activity: The spatial dynamics of industries in Canada 1971-2001. Growth and Change, 37(3), 362-395.

Przeworski, A., \& Teune, H. (1970). The Logic of Comparative Social Inquiry. New York: John Wiley \& Sons.

Rayle, L., \& Zegras, C. (2013). The Emergence of Inter-Municipal Collaboration: Evidence from Metropolitan Planning in Portugal. European Planning Studies, 21(6), 867-889.

Riguelle, F., Thomas, I., \& Verhetsel, A. (2007). Measuring urban polycentrism: A European case study and its implications. Journal of Economic Geography, 7(2), 193-215.

Roca, J., Marmolejo, C., \& Moix, M. (2009). Urban Structure and Polycentrism: Towards a Redefinition of the Sub-centre Concept. Urban Studies, 46(13), 2841-2868.

Rodríguez-Pose, A. (2013). Do Institutions Matter for Regional Development? Regional Studies, 47(7), 1034-1047.

Sager, F., Ingold, K., \& Balthasar, A. (2017). Policy-Analyse in der Schweiz. Besonderheiten, Theorien, Beispiele. Zurich: NZZ Libro.

Savitch, H., \& Kantor, P. (2002). Cities in the International Marketplace: The Political Economy of Urban Development in North America and Western Europe. Princeton: Princeton University Press.

Schneidewind, P., Tatzberger, G., Schuh, B., Beiglböck, S., Cornaro, A., Damsgaard, O., Dubois A., Gløersen, E., Benin, R. (2006). The Role of Small and MediumSized Towns (SMESTO). Final Report. Vienna.

Schuler, M., Dessemontet, P., Joye, D., \& Perlik, M. (2005). Die Raumgliederungen der Schweiz. Neuenburg.

Segessemann, A., \& Crevoisier, O. (2016). Beyond Economic Base Theory: The Role of the Residential Economy in Attracting Income to Swiss Regions. Regional Studies, 50(8), 1388-1403. 
Sellers, J. M., \& Lidström, A. (2007). Decentralization, local government, and the welfare state. Governance, 20(4), 609-632.

Serrano, J., \& Hamdouch, A. (2017). Inter-municipal cooperation as a means of creative territorial planning. In A. Hamdouch, T. Nyseth, C. Demazière, A. Førde, J. Serrano, \& N. Aarsaether (Eds.), Creative approaches to planning and local development. Insights from small and medium-sized towns in Europe (pp. 114133). Oxon: Routledge.

Servillo, Atkinson, R., \& Hamdouch, A. (2017). Small and Medium-Sized Towns in Europe: Conceptual, Methodological and Policy Issues. Tijdschrift Voor Economische En Sociale Geografie, 108(4), 365-379.

Shearmur, R., \& Coffey, W. J. (2002). A tale of four cities: Intrametropolitan employment distribution in Toronto, Montreal, Vancouver, and Ottawa-Hull, 1981-1996. Environment and Planning A, 34(4), 575-598.

Uyarra, E. (2010). What is evolutionary about 'regional systems of innovation'? Implications for regional policy. Journal of Evolutionary Economics, 20(1), 115-137. 


\section{Appendix}

Table A1: List of interview partners

\begin{tabular}{|c|c|c|c|c|}
\hline Nr. & Municipality & Function & Date & Duration \\
\hline 1 & Adliswil & Mayor & 27.06 .2017 & $60 \mathrm{~min}$ \\
\hline 2 & Adliswil & $\begin{array}{l}\text { Chairman of the town's business } \\
\text { association }\end{array}$ & 30.06 .2017 & $40 \mathrm{~min}$ \\
\hline 3 & Adliswil & Chairman of the town's historical society & 11.09.2017 & $45 \mathrm{~min}$ \\
\hline 4 & Adliswil & $\begin{array}{l}\text { Director of the region's economic and } \\
\text { local promotion association }\end{array}$ & 26.06.2017 & $90 \mathrm{~min}$ \\
\hline 5 & Adliswil & Parliamentarian & 05.07 .2017 & $60 \mathrm{~min}$ \\
\hline 6 & Adliswil & $\begin{array}{l}\text { Head of Public Affairs of a big company } \\
\text { located in town }\end{array}$ & 05.10 .2017 & $30 \mathrm{~min}$ \\
\hline 7 & Adliswil & $\begin{array}{l}\text { Former real estate project manager of a } \\
\text { big company located in town }\end{array}$ & 01.11 .2017 & $35 \mathrm{~min}$ \\
\hline 8 & Dübendorf & Mayor & 22.09 .2017 & $60 \mathrm{~min}$ \\
\hline 9 & Dübendorf & Head of town planning & 21.07 .2017 & $60 \mathrm{~min}$ \\
\hline 10 & Dübendorf & $\begin{array}{l}\text { Chairman of the town's business } \\
\text { association }\end{array}$ & 27.09.2017 & $60 \mathrm{~min}$ \\
\hline 11 & Dübendorf & $\begin{array}{l}\text { Director of the region's economic and } \\
\text { local promotion association }\end{array}$ & 08.08 .2017 & $60 \mathrm{~min}$ \\
\hline 12 & Dübendorf & $\begin{array}{l}\text { Local historians of the documentation } \\
\text { centre }\end{array}$ & 27.09 .2017 & $75 \mathrm{~min}$ \\
\hline 13 & Wädenswil & Mayor & 30.08 .2017 & $45 \mathrm{~min}$ \\
\hline 14 & Wädenswil & Head of planning and construction & 20.09 .2017 & $35 \mathrm{~min}$ \\
\hline 15 & Wädenswil & Local historian & 15.06.2017 & $60 \mathrm{~min}$ \\
\hline 16 & Wädenswil & $\begin{array}{l}\text { Board member of the town's business } \\
\text { association }\end{array}$ & 12.09 .2017 & $30 \mathrm{~min}$ \\
\hline 17 & Wädenswil & $\begin{array}{l}\text { Deputy municipal secretary and person } \\
\text { in charge of location promotion }\end{array}$ & 06.10 .2017 & $35 \mathrm{~min}$ \\
\hline 18 & Wädenswil & $\begin{array}{l}\text { Director of the town's university of } \\
\text { applied science }\end{array}$ & 14.09.2017 & $30 \mathrm{~min}$ \\
\hline 19 & Bülach & Member of the municipal council & 03.08 .2017 & $45 \mathrm{~min}$ \\
\hline 20 & Bülach & $\begin{array}{l}\text { Municipal secretary and head of } \\
\text { economic and location promotion }\end{array}$ & 08.08 .2017 & $45 \mathrm{~min}$ \\
\hline 21 & Bülach & $\begin{array}{l}\text { Chairman of the town`s industry } \\
\text { association }\end{array}$ & 28.09 .2017 & $40 \mathrm{~min}$ \\
\hline 22 & Bülach & $\begin{array}{l}\text { Director of the region's economic and } \\
\text { local promotion association }\end{array}$ & 14.07.2017 & $75 \mathrm{~min}$ \\
\hline 23 & Bülach & Historians of the local historical museum & 05.10 .2017 & $90 \mathrm{~min}$ \\
\hline 24 & Expert & $\begin{array}{l}\text { Director of the association Zurich } \\
\text { Metropolitan Conference }\end{array}$ & 15.06 .2017 & $90 \mathrm{~min}$ \\
\hline 25 & Expert & $\begin{array}{l}\text { Head of cantonal location promotion } \\
\text { department }\end{array}$ & 14.09 .2017 & $60 \mathrm{~min}$ \\
\hline
\end{tabular}


Table A2: Sample questionnaire

General development of the town

\begin{tabular}{|c|c|}
\hline & $\begin{array}{l}\text { Has the economic specialization rather been determined by the expansion of existing companies or the settlement of new } \\
\text { companies? }\end{array}$ \\
\hline \multirow[t]{3}{*}{ Town development policies } & What were the town development goals in recent years? \\
\hline & To what extent have these goals been achieved? \\
\hline & Have these goals changed over the years? How? Why? \\
\hline \multirow[t]{6}{*}{ Economic development policies } & What was the economic development strategy in recent years? \\
\hline & To what extent have these goals been achieved? \\
\hline & Have these goals changed over the years? How? Why? \\
\hline & $\begin{array}{l}\text { To what extent, do you think, local strategies/policies have an impact on the economic specialization and the economic } \\
\text { development of the town? }\end{array}$ \\
\hline & Which local strategies/policies have contributed decisively to the development of the economic specialization of the town? \\
\hline & How has/will the town position itself within the metropolitan region (in the future)? \\
\hline \multirow{6}{*}{$\begin{array}{l}\text { Specific local policies and their impact } \\
\text { (if not already mentioned above) }\end{array}$} & Innovation policies (cluster building, start-up promotion etc.) \\
\hline & Place-branding, image building? \\
\hline & Tax policy? Land-use policy? \\
\hline & Acquisition of firms? \\
\hline & Attraction of talent? Developing attractive living spaces? \\
\hline & Attraction of public funds for economic development? Cantonal or federal funds? \\
\hline \multirow{4}{*}{$\begin{array}{l}\text { Influence of cantonal and regional } \\
\text { policies/strategies on the local economic } \\
\text { specialization }\end{array}$} & To what extent does the town cooperate on economic development issues with other towns in the Zurich metropolitan region? \\
\hline & To what extent have regional strategies had/have an influence on the economic specialization and on town development? \\
\hline & To what extent did/do cantonal strategies influence the economic specialization and the development of the town? \\
\hline & To what extent has the town a say in regional and cantonal strategies? And, how? \\
\hline
\end{tabular}

To what extent has the economic structure developed in recent years (as far back as one can look), and why has this happened? What are the reasons that important companies/institutions have settled here?

Has the economic specialization rather been determined by the expansion of existing companies or the settlement of new panies?

To what extent have these goals been achieved?

What was the economic development strategy in recent years?

To what extent, do you think, local strategies/policies have an impact on the economic specialization and the economic

ment of the town?

To what extent has the town a say in regional and cantonal strategies? And, how? 